\title{
The Influence of Naqshbandi Sheikhs on Educational Process of Timurid Era
}

\author{
Maasumeh Goodarzi ${ }^{1} \&$ Aboulhassan Fayyaz Anoush ${ }^{1}$ \\ ${ }^{1}$ Department of History, University of Isfahan, Isfahan, Iran \\ Correspondence: Maasumeh Goodarzi, Department of History, University Of Isfahan, Azadi Square, Isfahan, Iran. \\ Tel: 98-913-212-4571. E-mail: Mitra_Goodarzi52@yahoo.com
}

Received: August 28, 2012 Accepted: November 6, 2012 Online Published: December 28, 2012

doi:10.5539/ach.v5n1p79

URL: http://dx.doi.org/10.5539/ach.v5n1p79

\begin{abstract}
In the ninth century (A.H.) the number of Sufis and their sects increased due to Timurids' attention to Sufis, and as a consequence convents (Khaneqa) became one of the most important economical and political centers. Excessive wealth and spiritual influence of Sufis leaders particularly Sheikhs of Naqshbani kingdom result in Sufism power being twice as much so that, Timurid kings and Sultans used their spiritual influence to legitimize their rules and tried not only to respect and honor them but also, to construct and operate their Khaneqas. Close relationship between Naqshbani's leaders and Timurid Sultans had a great influence on most country's affairs, particularly education and training as most of removal and installations in the field of educational affairs were under their views. In this survey, the impact of Naqshbandi's Sheikhs on educational process during Timurid period was investigated and analyzed by citing library references and implementing analytical-descriptive method.
\end{abstract}

Keywords: mysticism, Naqshbandieh, Timurid, education

\section{Introduction}

\subsection{Emergence Causes of Mystical Thoughts and Khaneqa Establishment}

The most important cause of mystical thoughts emergence should be found in contemporary circumstances. Some experts believe that mystical thoughts began to grow after the failing national uprisings and liberal movements. The frustration of Islam of Omavian and Abbasian which which in turn, resulted in violating deprived people and repressing the intellectual, was one of the most important and main factors of emerging mystical thoughts and Khaneqas establishment (Ravandi, 1997). While the former conquerors were getting accustomed to culture and knowledge of Iran, new nomads arrived and became a catastrophe for Iran; and these successive miseries and failures made Iranian people disappointed. As a direct result of these situations, Khaneqas were more prosperous, and the number and spread of their fans and leaders of these Khaneqa were increased by educated people (Sadri, 1971). Many researchers believe that rising of Mongols results in developing Sufism because distress and confusion were intensified, and following Mongols' invasion, economic, social, cultural and educational structures were changed. From this time onwards, Sufism did not suffice to ecstasy, description, preaching and advice but found a school, and then it was taught in the form of different sciences like words and wisdom. Since then Sufism has captured Persian literature in a strange intensity way and even affected and influenced Islamic culture of Iran (Ravandi, 1997). Most ministers of Ilkhanid period were interested in Sufism so they associated with the foundation centers of Khaneqa. Khawaja Shams al-din Mohammad Joyini. The author of 'Ilkhanid Government' book was one of the ministers who were interested in Sufism. He established a large Khaneqa in Tabriz (Mostoufi, 1960). From the first centuries of Islam, Khaneqa was considered as a place for gathering Sufis and they have done sensual austerity. Those people who were not satisfied with formal sciences, dropped out of schools and searched for certainty light by the guidance of Master. At first, Khaneqas and Sufis angles were as centers for teaching non-book sciences but gradually they were developed as same as schools with particular goals beside the educational systems (Dorrani, 1992).

\subsection{Sufism Development}

From Saljoghi period till Mongol's attack was prosperous and evolutionary time of Sufism in Iran and many Khaneqas were established across the country. At that time, Khaneqas were regarded as the goal-oriented 
organizations which that controlled educational methods. In other words, educational system of Khaneqas was such a non-book educational system (Petrushevskii, 1985. These centers had a particular role on Iranian scientific organizations from the seventh century (A.H.) because, on one hand, they were the same as holy shrines which had been protected against invasion and, on the other hand, they had become places for education, discussion, study and maintenance of Iranian cultural resources (Sadri, 1971).

\subsection{Sufism in Timurid Period}

One of the most important properties of Timurid period was the expansion and the great improvement of Sufism and Khaneqas growing. Timur deceitfully or sincerely displayed his special devotion to Sufis. His subordinates such as princes, rulers and commanders also began to follow him in religious and Sheikhs observance according to "People follow their leaders' beliefs", so during the rule of Timur and his successors, from the late of the eighth till the early of tenth centuries, the faith's position was remarkable and mosques and Khaneqas flourished. Religion and Sufism became closer to each other at schools and Khaneqas in a way that separation of Sharia and creed from each other was hardly possible (Mir Jaafari, 2006). School-building and the performance of schools were gradually altered due to the thrift of Sufism and the increase in the number of Khaneqas ; thus Sufis tended to have a great impact on Ilkhanid and Timurid sultans, rulers and ministers. Those centers which had been established in order to gain freedom from oppression of sultans tended to attract their protection. Timurid sultans had a great respect for Sufis and their approach resulted in the thrift of Sufism and development of Khaneqas. Honor and esteem of Khaneqas reached to such an extent that Amir Alishir Navayi took the sweeper position of Khwaja Abdullah Ansari's Khaneqa at Herat for a period of time (Khandmir, 1999).

\subsubsection{Sufism Centers as Educational Institutions}

Examples of educational and training centers during the domination of Timurid and Mongols were Khaneqas, Zaviye and Robats. These places were primarily used for education and non-book sciences but then they gradually changed into scientific and educational institutes. In addition to spiritual and mystical sciences, technical and scientific branches of science, which were previously taught at mosques and schools, were taught in these institutes as well (Nasr, 1971). These centers were considered as educational organizations not only because mystical sciences were taught there from the beginning, but also because they were responsible for the work of school houses and mosque schools. Khaneqas' operation and function were composed of educational programs of mosques, schools and homes and their main goal was nothing but Islamic and scientific education as well as sensual refinement (Kiani, 1990).

\subsubsection{Zaviye and Robat}

Zaviye and Robats along with the Khaneqas have played a pivotal role in Islamic educational history. These centers had been involved with schools and mosques in educational affairs and they also became successful to take a prominent position within the educational and training system (Ibn-i- Jamaa, 2009). The word "Robat" in Persian and Arabic was used in different meanings such as central station, inn, Khaneqa, guest house, fort, hospice, temple and shrine. From the sixth century onwards, by the development of Sufism and Sufis sects within the Islamic society, Robats took on new concept and they were considered as a place for worship, praying, education and training. Development and transformation of Robats began from Iran and expanded rapidly across the Islamic world (Ibn-i- Jamaa, 2009). Zaviye also was considered as a private and individual place like religious scholars room at the ancient schools. They had the similar application like Khaneqas and Robats and they also had a main role in developing educational culture (Kiani, 1990). Ibn Jamaee, according of Arbelis quotation, defines Zaviye as a small part of Khaneqa and describes KHaneqa as a men temple and Robat as a women temple (Ibn-i- Jamaa, 2009). Timurid rulers showed a real enthusiasm for building and constructing Khaneqas and had particular and special devotion to Sufis. Hafez Ebru stated that, "Shahrokh built a big school and Khaneqa in Heart which in its four porches, four reputable scientists were released science, talented scholars were gaining virtues and knowledge and read Quran and poor and deprived people used his table overnight (Hafez Ebru, 1991). Abd al-Rahman Jami acknowledged that the number of schools and Khaneqas in this period were more than other constructed buildings only with regard to the number of established school and Khaneqas by those people like Shahrokh and Hossein Bayqara (Jami, 1962). Sufism and its centers had unintentionally changed to Timurid legitimacy supplying factors. Referring to Javad Tabatabaei's words, political thought replaced by the Yasa of Genghis after Mongols invasion and widespread fall in Iran and whatever was remained from the golden culture of Iran was settled in Sufism Zaviyeas. The Iranian culture was driven to the deadlock of Sufism Zaviyeas and Sufis became the thinkers and teachers of people (Tabatabaei, 1994). Strong belief of Timurid kings and princes and their rulers in Sufis made ninth century a favorable period for the development of Sufism and Sufis' influence. Timurid history is full of authorities' commemorations of Sufis. Sufism found 
Sharia' colors at this age and differences between Sufism and Sharia's elders of centuries ago were rarely repeated. So, at that time, the separation of Sharia' companion from those creed companions was very difficult (Farhani, 2003).

\section{The Relationship between Mentor and Disciple and Its Influence on Education}

The role and position of spiritual man (Master, Mentor and Sheikh) are very remarkable in the Sufism creed. The mentor's duty is disciple's training who is obligated to peremptory obedience. They should not protest against the any action of their mentor but they should be honest in practice and never do stop demanding even if the entire world would become blade and fall on them.

The steadfast lover is someone who at the friend's house

Never turns his head even if sword falls on him

The disciples were responsible to say any news either good or evil to their mentors and not to hide anything from him as Sheikh was aware of their inner circumstances and talents (Samarqandi, 2009). Although Sheikh's respectability and obedience is necessary in many cases, the peremptory obedience of Sheikh caused to Sufism degeneracy and moral corruption. Most of Sheikhs wanted their disciples to be completely surrounded by their will and never forget Sheikh's face even when he was not with them. Their rationale was that they would be surrounded by his will and they would also become similar to him so that they would be lost in their Sheikh and would be propelled through the "Fana Fi Allah": (Integrating into/with God) (Louisen, 2005). Some Sheikhs stepped beyond this and were alone with disciples. But this relationship was not evident at schools because the educational relationship between student and teacher was a friendly one based on respect and it was not peremptory obedience. While students expressed their comments and criticism politely and obtained some desired results from the core of these disagreements which resulted in dynamism of science, the mentor and disciple relationship was as a blind obedience without dynamism. Sheikhs' words were proof for disciples. They claimed that veils would be removed by reaching God and these sciences will never be forgotten. Here, we should mention Saadi's comparison between school and Khaneqas regarding the consequences and impacts of reaching ways to science.

Mystic came to school from Khhaneqa and abjured the speak of religious men

I said "what is the difference between scientist and abstemious men?" that some people choose it among them

He takes his rug out of water (just think about himself) but the second one makes an attempt to rescue sinker (SAADI, 1977:890)

\section{Naqshbandi Creed and Its Impact on Educational System}

Naqshbandi creed is referred to Khwaja Bahauddin Mohammad Naqshband Bukhari (717-791 A.H.) but he was not its founder. This creed in fact is the follow of Khawjegan creed which had been established by Khawja Yousef Hamadani (440-535 A.H.) and Khawja Abdulkhaliq Qajvadani (Vaez, 1977). Naqshbandi was a mixture of Abdulkhaliq Qajvadani and Bahauddin Bukhari teachings. These teachings were rapidly prospered in Khorasan and Khawja Bahauddin who was trained by Qajvadani successors became the reformer of Khawjegan creed. After Bahauddin his successors Aladdin Attar (dead 802 A.H.), Mohammad Parsa (822 A.H.), Yaghoub Charkhi (851 A.H.) and Khawja Abido-Allah Ahrar (806-895 A.H.) relied on this bench and were regarded as the most famous sheikhs of Timurid period (Parsai, 1975). In the ninth century (A.H.) they became very powerful and influential and played a key role in many of happenings and events in Khorasan. In many of battles, chaoses and compromises Naqshbandi' footprints could be seen. The Timurid kings respected them and sometimes they valued them excessively (Parsai, 1975). Sheikhs of Naqshbandi were moderate in politics but they were fanatic in religion as much as their contemporary kings and Sultans (Yarshater, 1955). Naqshbandis' moderation and also their commitment to Sharia' made princes, Sultans and many of scholars close to this creed (Parsai Bukhari, 1975). The kings after Timur, Shahrokh and Sultan Hossein Biqra devoted Sheikhs and took advice from them about the world and resurrection issues. As a result, great Masters and several Sheikhs emerged throughout the territory of Shahrokh, many khaneqas were constructed and many people came to visit Sheikhs from different parts. They received gifts for grace and understanding (Nezami, 2004). Although Timurid princes respected and celebrated religious scholars and Sufism Sheikhs because of religious beliefs and had a special devotion to them, this respect was not only because of mental sciences and wisdom distribution but also because of legitimacy and advancement of political objectives. In this period, great sects of Sufism creed such as Nematalahi, Naqshbandi, Safavieh and Noor Bakhshiye emerged. But Timurid's princes had the close colorful relationship with Naqshbandi's Sheikhs. This powerful relation was certainly due to moderation of Masters of Naqshbandi. Consequently, unlike the past, Sheikhs of Naqshbandi could have influence on political issues and were 
promoted dramatically (Mobarak, 1992; Jaami, 1982). Some Sheikhs communicated with Sultans in order to meet the needs of people and mediated between court and people. The majority of these Sheikhs were seeking for authority and fame. Some Timurid Sultans tended to Sufism because of their fear of Faqihs' domination and endeavored unintentionally to strengthen Sufism position (Zarrinkoob, 1990). The Sheikhs of Naqshbandi based on one of their ideological principles, namely "chat in forum", which apparently meant to be with the people and certainly be with the God, believed that they should always do some tasks of apparent works so they wouldn't be distinguished from others and Sharia' would be strengthened by their assistance and domination. They claimed that this power and domination would not be enabled without the support of kings and Sultans. So, they tried so much to approach contemporary kings' domination. Having relations with kings and Sultans, made a prominent position for this sect. Consequently, people were attracted by it more and more (Mir Jaafari, 2006). It is just because sheikhs accepted to believe the interpretational statements and opinions of Sufism Masters theoretically, and gradually accommodate with the political authority in practice, during the time when, due to the emergence of government-fighting Sufism which was fed by the verdicts of such Shia' and interpreters as Sufism that there could exist a creed like Naqshbandi in Harat.

In particular during the authority of Sultan Hossein Biqra, Sufism showed amenity about governmental issues and Naqshbandi sheikhs dominated on the most social relations and were responsible for revitalization of their land's cultural life. Naqshbadie was developed in Herat by Saadul Din Kashqari and Abdul Rahman. Subsequently, it became one of the association centers of Naqshbadis (Mobarak, 1992). Abdul Rahman Jami was also one of the most famous figures of Timurid who was admired by his contemporary kings, scholars and Masters. He had great influence on his contemporary events (Nezami, 2004). Edward Brown claimed that there was no one resembling to him in science (Brown, 1972). Abdul Rahman Jami joined to Naqshbandi for a period of his life and also became a rectorate (Jami, 1962). Because at that time educational system was influenced by Naqshbandi creed, his joining to Naqshbandi influenced his academic life and his educational theories. For example, he considered women as being imperfect creature so they could not be reliable and they could not learn sciences (Saddiq, 1953). Based on Timurid documents, Naqshbandis remarkably had a great impact on educational issues trends. Their influence reached to the point that most of the removals and installations in educational field were according to Sheikhs' views. Even the selection of teachers and courses were in their authority area. Since this sect's Masters did not have close relationship with Shia', when they had suspicion about teachers and scholars of being Shia' they rapidly either dismiss or even exile them. Saen al-Din Torke Esfahani was the scholar who was taken umbrage by Shahrokh as the result of the attempts of Naqshbandi's Sheikhs. He went to Khorasan in order to protect himself from abusive and then was graced by Shahrokh and was assigned to judging position of Yazd. In the year of 830 A.H., followed by hand to assassinate to Shahrokh by Ahmad Lore, Saen al-Din was sentenced to jail and also his properties were confiscated. He described these events in the Almasdour plan, his book, for the son of Shahrokh, Baysonghor, and complained of the injustice. Saen al-Din complained of these unkindness and claimed that, "as everyone who said this poor man hello did not see good day, they were harassed, seized homes, I was confined in the castle and did not let anyone to come to visit me" (Torke, 1972). Molana Marouf, the famous calligrapher of Alexander Mirza's court, was another person who was taken umbrage by Naqshbandi's Sheikhs. He was transferred to Heart followed by the victory of Shahrokh over Alexander and served as a scribe of Shahrokh but since the Naqshbandi's Sheikhs were not satisfied with his presence in the court of Shahrokh and he was charged followed by hand to assassinate to Shahrokh, sentenced to death several times and finally he was confined in the well of Ikhtiar al-Din's castle in Herat and died in prison (Monshi, 1973). Naqshbandi's traces can be seen in all of these charges, exiles and desecrations. Whenever these Sheikhs felt that their positions would be at the risk of being undermined by other sects, they tried to make arrangements for their fall.

\section{Conclusion}

In the eighth century (A.H.), Khaneqa's Sufism was thriven throughout Iran, India and minor Asia overly. Other Sciences and knowledge were slowly replaced by Sufism sciences and most of scientific achievements were affected by Sufism beliefs. High power of Sufism and the prominent presence of Naqshbandi's elders who had high influence and power in this age were important indicators of Timurid period. It could be claimed, according to the earlier and later experts' views, (Vaez, 1977; NoShahi, 2001) that most of Naqshbandi's Sheikhs avoided learning apparent sciences and they were not successful at formal educations; however, these Sheikhs had a detrimental impact on the education of Timurid period. Most of educational installations and removals were influenced by their views, even teacher selections and training courses were their responsibility. Ultimately dogmatic thoughts of Sheikhs caused led to stagnation of interpretation and wisdom sciences. 


\section{References}

Brown, E. (1972). The Historiocal Literature of Iran from Saadi to Jammi (p. 671). Tehran: Ibn - Sina Publication.

Dorrani, K. (1992). History of Education in Prior to the Advent of Islam and thereafter (p. 106). Tehran: Samt Publication.

Farhani, M. M. (2003). Politics and Culture at the end of Timurid and early Safavied Period (p. 234). Tehran: Society for the Appreciation of Cultural Works and Digmtaries.

Hafez, E. S. A. (1991). In G. Varahram, Historic Geography of Khorasan (p. 13). Tehran: Etelaat Publication.

Ibn - I - Jamau, B. (2009). Instructive Procedures (pp. 108-112). Tehran: Ney Publication.

Jaami, N. A. (1962). Perfect Divan of Jami (pp. 50, 164). Tehran: Pirooz Publication.

Jaami, N. A. (1982). Haft Ourang (p. 384). Tehran: Saadi Publication.

Khandmir, G. (1999). Makarem ul Aklagh (In Arabic). Tehran: Miras Nashr Maktoob Publication.

Kiani, M. (1995). Khaneqas History of Iran (pp. 37-98). Tehran: Tahery Publication.

Lewisohn, L. (2005). The Heritage of Sufism (Vol. 2, p. 66). Tehran: Markaz Publication.

Mirjaafari, H. (2006). The History of the Political, Social, Economic and Cultural Changes in Iran during the Timurid and Turkaman Period (pp. 177-178). Tehran: Samt Publication.

Monshi, Q. G. (1973). The Garden of Art (pp. 26-27). Tehran: Manochehri Library.

Mostoufi, H. (1960). Special History (p. 230). Tehran: Amir Kabir Publication.

Mubarak, B. S. (1992). Anis al - Taliban - Vauddat al - Salikin (In Arabic) (pp. 10-11). Tehran: Keyhan Publication.

Nasr, S. H. (1971). Science and Civilization in Islam (p. 78). Tehran: Andishe Publication.

Nazemi, B. A. (2004). Positions of Jaami. Edited by Najib Mayel Hervi. Tehran: Ney Publication.

Noshahi, A. (2001). The Biography of Khawja Obeidullah Ahrar (pp. 7-8, 150-151). Tehran: University Publication.

Parsai, B. K. M - ibn - M. (1975). Qodsieh (p. 11-15). Tahery Publication, Tehran.

Petrushevskii, I. P. (1985). Islam in Iran (p. 345). Tehran: Payam Publication.

Raavandi, M. (1997). Social History of Iran (Vol. 9, pp. 328-391). Stockholm: Arash Publication.

Saadi, M. A. (1977). Kolliat Saadi (p. 890). Mohammad Ali Foroughi. Tehran: Amir Kabir Publication.

Saadiq, I. (1953). Cultural Trend in Iran and West (p. 494). University of Tehran. Tehran.

Sadri, G. (1971). History of Institution and Organization in Iran (p. 118). Tehran: Publication of Science and Instruction Ministry.

Samarqandi, M. (2009). Seselatul Arephin and Tazkeratul Sedighin (p. 72). Tehran: Library and Museum Document Center of Islamic Council Majless.

Tabatabaei, S. J. (1994). Decline of Political Thought of Iran (pp. 231-232). Tehran: Kavir Piblication.

Torke, E. S. (1972). Fourteen Thesis in Persian (p. 205). Tehran: Ferdousi Publication.

Vaezi, K. F. A. (1977). Rashahat ul Einulhayat. (In Arabic) (Vol, 7. pp. 35-36, 408). Iran: Noriani Publication.

Yar - e - Shater, E. (1995). Persian Poem of Shahrokh Era (p. 20). University of Tehran. Tehran.

Zarrinkoob, A. (1990). The Value of the Heritage of Sufism (p. 160). Tehran: Amir Kabir publication. 